\title{
Effect of Protein Levels, Ascorbic Acid and their Interaction on Performance of Colour Hen during Pre and Post Summer Periods
}

\author{
S. S. Atkare ${ }^{1 *}$, Laxmi Chouhan ${ }^{1}$, Girraj Goyal ${ }^{1}$, A. S. Shinde ${ }^{2}$ and L. S. Shekhawat ${ }^{2}$ \\ ${ }^{1}$ Department of Poultry Science, College of Veterinary Science and Animal \\ Husbandry, N.D.V.S.U., Jabalpur, India \\ ${ }^{2}$ Instructional Dairy Unit, College of agriculture, J.N.K.V.V., Jabalpur, India \\ *Corresponding author
}

\begin{abstract}
A B S T R A C T
Dual type colour hens were evaluated for performance traits during pre summer $\left(92.4^{0} \mathrm{~F}\right.$ to $100.3^{\circ} \mathrm{F}$, average $\left.95.3^{0} \mathrm{~F}\right)$ and post summer $\left(101.7^{0} \mathrm{~F}\right.$ to $106.3^{\circ} \mathrm{F}$, average $\left.104.6^{0} \mathrm{~F}\right)$ periods,

feeding $\mathrm{P}_{1}(15 \% . \mathrm{CP}), \mathrm{P}_{2}(16.5 \% . \mathrm{CP})$ and $\mathrm{P}_{3}(18 \% . \mathrm{CP})$ protein diet with ascorbic acid $(250 \mathrm{mg} / \mathrm{kg})$ supplementation. Feed intake/hen/day and egg production/hen/period was significantly higher $(\mathrm{P}<0.05)$ in $\mathrm{P}_{2}$ than $\mathrm{P}_{1}$ and $\mathrm{P}_{3}$ during both summer periods. Egg weight of $\mathrm{P}_{2}$ and $\mathrm{P}_{3}$ was non significant in pre summer whereas during post summer, $\mathrm{P}_{2}$ egg weight was significantly higher than $\mathrm{P}_{1}$ and $\mathrm{P}_{3}$. Feed efficiency/kg egg mass in $\mathrm{P}_{2}$ and $\mathrm{P} 3$ was non significantly different and significantly better than $\mathrm{P} 1$. During post summer feed efficiency (FE) improved significantly $(\mathrm{P}<0.05)$ with increasing protein levels. Feed Intake $(\mathrm{FI})$, egg production (EP), egg weight was decreased in post summer than pre summer in the range of $13.64 \%$ to $23.28 \%, 5.28 \%$ to $12.81 \%$ and $2.71 \%$ to $6.25 \%$ respectively. An adverse effect on FI was higher, followed by egg production than egg weight. FE improved in the range of $3.78 \%$ to $9.17 \%$ shown higher improved in P3 high protein diet. Ascorbic acid supplementation $(250 / \mathrm{mg} / \mathrm{kg})$ significantly improved FI and EP in both summer period, Egg wt in pre summer and $\mathrm{FE}$ in Post summer period. Treatment $\mathrm{P}_{2} \mathrm{XC}_{1}$ has higher feed intake, egg production, egg weight and feed efficiency/ kg egg mass during pre and post summer period.
\end{abstract}

Keywords

Colour hens,

Protein, Ascorbic acid, Interaction, Performance, etc.

\section{Article Info}

Accepted:

07 October 2020

Available Online:

10 November 2020

\section{Introduction}

Protein and energy are major dietary components of feed formulation. Its requirement and efficiency of utilization has been found to be influenced by genotype and environment. In tropical countries summer temperature varies from $32^{\circ} \mathrm{C}$ to $46^{\circ} \mathrm{C}$. Higher temperature causes decrease performance of birds through reduced feed intake, nutrient utilization, high body temperature and disturbed physiology and metabolic process. Under heat stress excess plasma corticosterone hormones are released which adversely influence physiology and metabolic process in birds. Increase body temperature causes tissue damage and release of intracellular substances. Ascorbic acid (AA) has been found to limit rise in circulatory corticosterone concentration (Sahin et al., 
2002), body temperature (Pardue et al., 1985). Dietary supplementation of ascorbic acid (AA) improves performance of birds. Contradictory finding are also reported in literature (De faria et al., 2001). In view of this context, dual type Jabalpur colour hens were evaluated for performance traits under pre and post summer periods, feeding varying protein levels with ascorbic acid supplementation.

\section{Materials and Methods}

Fourty week age 108 dual type colour hens were randomly housed in individual cages in six dietary treatment groups. Each group had 18 birds in 3 replicates. Ration containing $15 \%, 16.5 \%$ and $18 \%$ crude protein with 2700 $\mathrm{kcal} \mathrm{ME} / \mathrm{kg}$ diet were prepared. All three ration were supplemented with ascorbic acid (250mg/kg diet) and its counter- part without AA, making 6 dietary treatments. Experiment conducted for 84 days form 25 Feb to 19 May as pre summer and post summer periods, each one of 42 days duration. Daily egg production and egg weight was recorded and compiled weekly and 6 wk pre and post summer periods. Replicate wise egg mass in each week and in each 6 week period was estimated. Daily measured amount of feed was given to replicated group of birds to determine feed efficiency/Kg egg mass. Ambient shed temperature was recorded daily 3 times (10am, 2pm and 5pm) and its average calculated for weekly and periodically. Collected data was analyzed as per Snedecor and Cochran (1994) and means were tested for significance of difference.

\section{Results and Discussion}

Shed temperature measured 3 times daily was range between $92.4^{0} \mathrm{~F}$ to $100.3^{0} \mathrm{~F}$ (Av. 95.3 ${ }^{0} \mathrm{~F}$ ) during pre summer and $101.7^{0} \mathrm{~F}$ to 106.3 ${ }^{0} \mathrm{~F}$ (Av. 104.6 ${ }^{0} \mathrm{~F}$ ) during post summer period. Increasing dietary protein from $\mathrm{P} 2$ to $\mathrm{P} 3$ level result in significant $(\mathrm{P}<0.05)$ decreased FI at level of $11.28 \mathrm{~g} /$ hen/day during pre summer and $19.53 \mathrm{~g} / \mathrm{hen} /$ day during post summer. P1 and P3 were non significant during pre summer whereas during post summer P3 has significantly $(\mathrm{P}<0.05)$ lowest feed intake. Dhagir (1996) and Lin et al., (2006) reported decreased FI and performance of hens fed high protein diet under high environment temperature. The result was in agreement to these authors. Increased ambient shed temperature form $95.3^{\circ} \mathrm{F}$ (range $92.4^{0} \mathrm{~F}$ to $100.3^{0} \mathrm{~F}$ ) to $104.6^{0} \mathrm{~F}$ (range $101.7^{0} \mathrm{~F}$ to $106.3^{\circ} \mathrm{F}$ ) during post summer decreases FI of P1, P2, P3 protein diet at level of $13.9 \mathrm{~g}$ (13.46\%), 16.30g. (13.94) and 24.6g $(23.28 \%)$ respectively, indicated higher decrease in high protein diet. Ebeid et al (2012) and Attia et al., (2016) Stated that bird consume less feed to decrease body heat increment associated with nutrient metabolism.

Egg no./hen/ period were significantly higher $(\mathrm{P}<0.05)$ in $\mathrm{P} 2$ than $\mathrm{P} 1$ and $\mathrm{P} 3$ protein levels during both summer period. P1 and P3 were non significant. Experiments conducted in summer climate revealed detrimental effect of high protein under high summer temperature. (Dhagir, 1996; Tyagi and Serajuddin, 2007; Sahin, et al., 2009) The present result supported these authors. The egg no./hen during post summer period were decreased by 1.44 egg (5.28\%), 3.03 egg (10.60\%) and 3.35 egg $(12.81 \%)$ in $\mathrm{P} 1, \mathrm{P} 2, \mathrm{P} 3$ protein levels respectively with increased average shed temp from $95.3^{0} \mathrm{~F}$ to $104.6^{0} \mathrm{~F}$. These values also shown higher decrease in high protein diet. Significantly lower egg production with increased ambient temperature was reported by Sahin et al (2009) and Attia et al (2016). As the environment temperature rises above $90{ }^{0} \mathrm{~F} \quad\left(32.2{ }^{0} \mathrm{C}\right)$, temperature regulatory mechanism not adequate to control body temperature near normal range resulting in heat stress. Release of excess corticosterone 
in heat stressed bird, adversely affect physiological and metabolic process, resulting lower performance of birds (Pardue et al., 1985).

Egg weight of $\mathrm{P}_{2}$ was non significantly different from $\mathrm{P}_{3}$ during pre summer whereas significantly higher in post summer, indicated some lower sensitivity of egg weight than feed intake and egg production. $\mathrm{P}_{1}$ egg weight was significantly lower in both summer. In comparison to pre summer, egg weight in post summer was depressed by $1.44 \mathrm{~g}(2.7 \%) 3.03 \mathrm{~g}$
(5.54\%) and $3.35 \mathrm{~g}(6.24 \%)$ respectively in $\mathrm{P}_{1}$, $\mathrm{P}_{2}, \mathrm{P}_{3}$ protein diet. Depression in egg weight was recorded lower than feed intake and egg production. Similar finding was reported by Ebeid, et al (2012) and song, et al (2012). Feed efficiency/kg egg mass was improved with increasing protein level in diet with non significant difference between P2, P3 in pre summer and significant in post summer. Parson et al (1993) and Zou and Wu (2005) reported significantly better FE with increasing dietary protein level (Table 1).

Table.1 Effect of protein and ascorbic acid on performance of colour dual type hens during pre and post summer periods

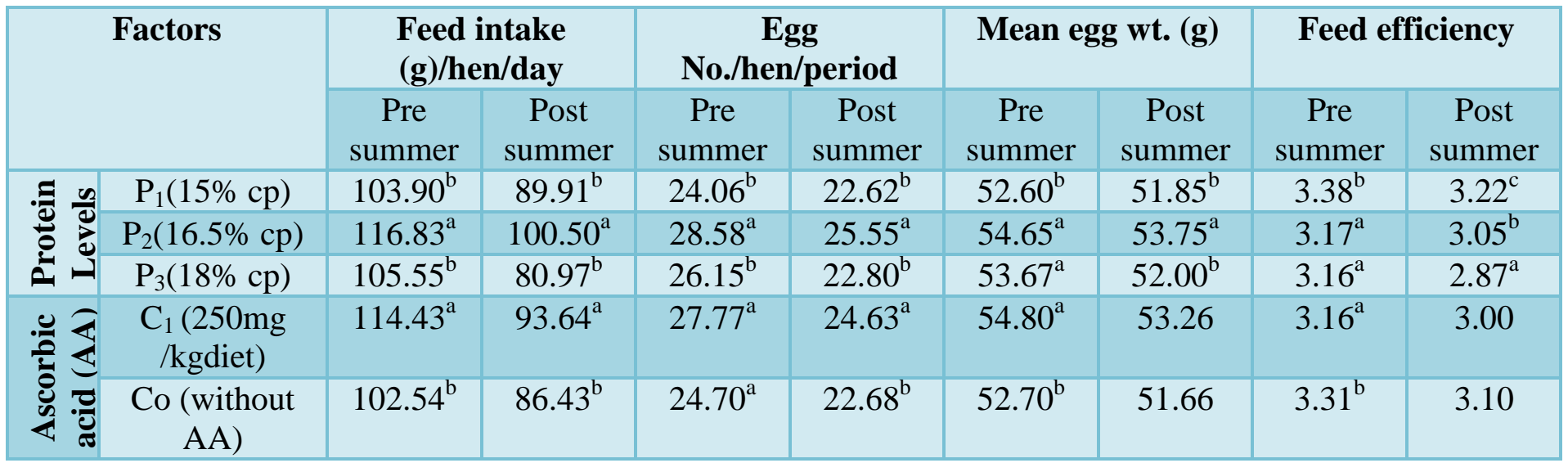

Means within a column for each factor with different superscripts differ significantly $(\mathrm{P}<0.05)$

Table.2 Effect of protein $\mathrm{x}$ ascorbic acid interaction on performance of colour dual hens during pre and post summer periods

\begin{tabular}{|c|c|c|c|c|c|c|c|c|}
\hline \multirow[t]{2}{*}{ Factors } & \multicolumn{2}{|c|}{$\begin{array}{l}\text { Feed intake } \\
\text { (g)/hen/day }\end{array}$} & \multicolumn{2}{|c|}{ Egg No./hen/period } & \multicolumn{2}{|c|}{ Mean egg wt. (g) } & \multicolumn{2}{|c|}{ Feed efficiency } \\
\hline & $\begin{array}{c}\text { Pre } \\
\text { summer }\end{array}$ & $\begin{array}{c}\text { Post } \\
\text { summer }\end{array}$ & $\begin{array}{c}\text { Pre } \\
\text { summer }\end{array}$ & $\begin{array}{c}\text { Post } \\
\text { summer }\end{array}$ & $\begin{array}{c}\text { Pre } \\
\text { summer }\end{array}$ & $\begin{array}{c}\text { Post } \\
\text { summer }\end{array}$ & $\begin{array}{c}\text { Pre } \\
\text { summer }\end{array}$ & $\begin{array}{c}\text { Post } \\
\text { summer }\end{array}$ \\
\hline $\mathbf{P}_{1} \times C_{1}$ & $105.1^{\mathrm{bc}}$ & $93.5^{\mathrm{a}}$ & $24.07^{\mathrm{cd}}$ & $23.2^{\mathrm{bc}}$ & $53.0^{c}$ & $52.0^{\mathrm{bc}}$ & $3.37^{\mathrm{c}}$ & $3.25^{\mathrm{b}}$ \\
\hline $\mathbf{P}_{2} \times C_{1}$ & $120.8^{\mathrm{a}}$ & $100.2^{\mathrm{a}}$ & $30.6^{\mathrm{a}}$ & $26.6^{\mathrm{a}}$ & $55.3^{\mathrm{a}}$ & $54.5^{\mathrm{a}}$ & $3.00^{\mathrm{a}}$ & $2.90^{\mathrm{a}}$ \\
\hline $\mathbf{P}_{3} \times C_{1}$ & $114.4^{\mathrm{b}}$ & $86.7^{\mathrm{b}}$ & $28.0^{\mathrm{b}}$ & $24.0^{\mathrm{bc}}$ & $55.0^{\mathrm{ab}}$ & $53.3^{\mathrm{ab}}$ & $3.12^{\mathrm{b}}$ & $2.85^{\mathrm{a}}$ \\
\hline $\mathbf{P}_{1} \mathbf{x C}_{0}$ & $99.6^{\mathrm{cd}}$ & $85.0^{\mathrm{bc}}$ & $23.4^{\mathrm{d}}$ & $22.0^{\mathrm{cd}}$ & $52.6^{\mathrm{c}}$ & $50.7^{c}$ & $3.40^{\mathrm{c}}$ & $3.20^{\mathrm{b}}$ \\
\hline $\mathbf{P}_{2} \times C_{0}$ & $113.2^{\mathrm{b}}$ & $98.6^{\mathrm{a}}$ & $26.5^{\mathrm{bc}}$ & $24.4^{\mathrm{b}}$ & $53.5^{\mathrm{bc}}$ & $53.0^{\mathrm{ab}}$ & $3.35^{\mathrm{c}}$ & $3.20 \mathrm{~b}$ \\
\hline $\mathbf{P}_{3} \times C_{0}$ & $100.8^{\mathrm{d}}$ & $76.5^{c}$ & $24.3^{d}$ & $21.6^{d}$ & $52.3^{c}$ & $51.3^{c}$ & $3.20^{\mathrm{b}}$ & $2.90^{\mathrm{a}}$ \\
\hline
\end{tabular}

Means within column with at least one common superscripts are non significantly different $(\mathrm{P}<0.05)$ 
The present result was in agreement during post summer of high ambient temperature and partially supported in pre summer of lower ambient temperature. Feed efficiency/kg egg mass was recorded superior in post summer than pre summer of comparatively lower environment temperature.

Ascorbic acid (AA) supplementation @ $250 \mathrm{mg} / \mathrm{kg}$ significantly improved FI/hen during pre and post summer periods. The result collaborated with the finding of Sahota and Gillani (1995), Cheng et al (1990). Mean egg no./hen/period was significantly better in ascorbic acid (AA) supplemented diet during pre and post summer whereas mean egg weight shown significantly different during pre summer of lowers ambient shed temperature. Panda, et al (2007) reported significantly improved egg production and non significant effect on egg weight of hens, supplemented $250 \mathrm{mg} / \mathrm{kg}$ ascorbic acid (AA) in diet. Whereas, Ciftsi, et al., (2005) reported significantly higher egg weight and egg production of hens supplemented $250 \mathrm{mg} / \mathrm{kg}$ ascorbic acid (AA) in diet. The present experiment conducted in two summer temperature regimes, shown beneficial effect of ascorbic acid (AA) on egg weight during pre summer having comparatively lower temperature than post summer. Feed efficiency/kg egg mass was significantly improved during pre summer where as non significant difference observed during post summer period of high ambient temperature. Significantly improved FCR with ascorbic acid (AA) supplementation during summer $\left(31-45^{0} \mathrm{C}\right)$ was reported by (Abd-Ellah, 1995, Sahota and Gillani 1995 and Panda et al., 2007). The present study result supported above authors during pre summer but having contrary finding in post summer of high ambient temperature.

Protein $\times$ AA interaction result (Table 2) shown significantly higher FI/hen/day and egg production/hen/ period in $\mathrm{P}_{2} \times \mathrm{C}_{1}$ treatment during both summer period. Mean egg weight was also found higher in $\mathrm{P}_{2} \times \mathrm{C}_{1}$ with non significant difference from $\mathrm{P}_{3} \times \mathrm{C}_{1}$ and significant from all other $\mathrm{P} \times \mathrm{C}$ combinations. Feed efficiency/ kg egg mass during pre summer was significantly superior in $\mathrm{P}_{2} \mathrm{C}_{1}$ where as during post summer $\mathrm{P}_{2} \mathrm{C}_{1}$, $\mathrm{P}_{3} \mathrm{C}_{1}$ and $\mathrm{P}_{3} \mathrm{C}_{\mathrm{o}}$ were non significant different and significantly better than other $\mathrm{P} \times \mathrm{C}$ combinations.

The results concluded that $\mathrm{P}_{2}$ dietary protein improve feed intake, egg production, egg weight and feed efficiency during both summer period. Feed intake and egg production traits were found sensitive to $\mathrm{P}_{3}$ higher protein diet in both pre and post summer temperature range whereas egg weight influenced adversely in post summer of high shed temprature. Increased temperature in post summer result in higher percent decrease in feed intake followed by egg production than egg weight. AA 250 $\mathrm{mg} / \mathrm{kg}$ improved FI and egg production significantly during pre and post summer whereas egg weight and feed efficiency $/ \mathrm{kg}$ egg mass improved significantly during pre summer. Interaction result shown that $\mathrm{P}_{2} \times \mathrm{C}_{1}$ treatment improved feed intake, egg production, egg weight, with better feed efficiency during both summer periods compared to other $\mathrm{P} \times \mathrm{C}$ combinations.

\section{References}

Abd-ellah, A.M. (1995). Effect of ascorbic acid supplementation on performance of laying hens during hot summer months. Assiut Veterinary Medical Journal, 34: 83-95.

Attia, Y.A., ABD, E.A., Abedulla, A.A., Berika, M.A., Al-Harthi, M.A.Kucuk, O., Sahin, K. and Abou-Shehema, B.M. (2016). Laying performance, digestibility and plasma hormones in laying hens exposed to chronic heat stress as affected by betain, vitamin C, and/or vitamin E supplementation. Worlds 
Poultry Science Journal, 5: 1619-30.

Cheng, T.K., Coon, C.N. and Hamre, M.L. (1990). Effect of environmental stress on the ascorbic acid requirement of laying hens. Poultry Science, 69: 774-778.

Çiftci ,M., Nihat-Ertas, O., Guler, T. (2005). Effects of vitamin $\mathrm{E}$ and vitamin $\mathrm{C}$ dietary supplementation on egg production and egg quality of laying hens exposed to a chronic heat stress. Veterinarica, 156:107-111

Daghir, J. N. (1996). Nutrition and climatic stress. Proceeding XX World Poultry Congress, New Delhi, India. 2-5 September (1): 141150.

De Faria, D.E., Junqueira, O.M., Souza, P.A. and Titto, E.A.L. (2001). Performance, body temperature and egg quality of laying hens fed vitamins $\mathrm{D}$ and $\mathrm{C}$ under three environmental temperatures. Brasilian Journal of Poultry Science 3: 49-56.

Ebeid , T.A., Suzuki, T. and Sugiuama, T. (2012).High ambient temperature influences egg shell quality and calbindin-D28k localization of egg shell gland and all intestinal segment of laying. Poultry Science, 91: 2282-2287.

Lin ,H., Jiao H.C. Buyse ,J. and Decuypere ,E.(2006). Strategies for preventing heat stress in poultry. World Poultry Science Journal, 62: 71-86.

Panda, A.K., Ramarao, S.V. and Raju, M.V.L.N. (2007). Effect of vitamin C supplementation on performance, immune system and antioxidant status of heat stressed white leghorn layer. Indian Journal of Poultry Science, 2: 169-173.

Pardue, S.L., Thaxton, J.P. and Brake, J. (1985) Role of ascorbic acid in chicks exposed to high environmental temperature. Journal of Applied Physiology, 58: 1511-1516.

Parsons, C.M., Koelkebeck, K.W., Zhang, Y.,
Wang, X. and Leeper, R.W. (1993). Effect of dietary protein and added fat levels on performance of young laying hens. Journal of Applied Poultry Research, 2: 214-20.

Sahin, K., Sahin, N. and Yaralioglu, S., (2002). Effect of vitamin $\mathrm{C}$ and vitamin $\mathrm{E}$ on lipid peroxidation, blood serum metabolites and mineral concentration on laying hens at high ambient temperature. Biological Trace Elements Research 85:35-45.

Sahin, K., Sahin, N., Kucuk,O., Hayirli, A., and Prasad, A.S. (2009). Role of dietary zinc in heat stressed poultry :A review. Poultry Science. 88:2176-2183.

Sahota, A.W. and Gillani, A.H. (1995). Effect of ascorbic acid supplementation on performance and cost of production in layers maintained under high ambient temperatures. Pakistan Veterinary Journal, 15: $155-158$.

Snedecor, G. W., \& Cochran, W. G. (1994). Statistical methods. Calcutta, India: Oxford \& IBH Publication, New Delhi.

Song, Z. Liu, L. Sheikhahmadi, A., Jiao, H. and Lin, H.(2012).Effect of Heat Exposure on Gene Expression on feed intake regulatory peptides in laying hens. Journal of Biomedicine and Biotechnology. 1-8.

Tyagi, S.S. and Serajuddin, M. (2007). Nutritional intervention for alleviating heat stress in poultry. Proceeding XXIV IPSACON. 2527 April. 2007. Guru Angad Deo Veterinary and Animal Science University. Ludhiana pp 147-150.

Zou, X.T. and Wu, Y. Z. (2005). Effect of protein supplemental fat on performance of laying hens. International Journal of Poultry Science, 4: 286-89.

\section{How to cite this article:}

Atkare, S. S., Laxmi Chouhan, Girraj Goyal, A. S. Shinde and Shekhawat, L. S. 2020. Effect of Protein Levels, Ascorbic Acid and their Interaction on Performance of Colour Hen during Pre and Post Summer Periods. Int.J.Curr.Microbiol.App.Sci. 9(11): 645-649.

doi: https://doi.org/10.20546/ijcmas.2020.911.079 